\title{
The Individuated Collective Utterance: Lack, Law and Desire in the Autobiographies of Ellen Kuzwayo and Sindiwe Magona*
}

\author{
Kgomotso Masemola
}

\begin{abstract}
Summary
This article signposts the discussion of autobiographical selfing through figures of cultural memory that are a function of double consciousness and double temporality. Two exemplary autobiographies, one by Ellen Kuzwayo and one by Sindiwe Magona, are shown to evince complex ontological formations between which the gap in representing the self of experience and the writing self is radically repeated in the multiplicity of individual articulation of collective agency. The paradox of individual-collective articulation bespeaks the "gap" of writing in double temporality. The article explores that "gap" between Darstellung and Vertretung1 on the premise that it evocatively refers to the slippage or instability of "Truth" written from the exergue of margins of the borderline texts of remembrance in the autobiographies of two black women. For these women's writing runs parallel - and gives testimony to their central involvement in the urban township communities as social workers and mothers or, if you will, private and public figures. In this politicised private-public dialectical movement, the autobiographies under discussion take on a Kafkaesque dimension of what Deleuze \& Guattari (1986) consistently call a "minor literature". The article ultimately brings to view the extent to which the mark of history as a territorial machine is inscribed upon the body of the autobiographical subject, and how it produces a representational crisis that unwittingly provides - rather than strictly regulates - the conditions of possibility for even more radical memoric testimony to history and becoming in selfwriting.
\end{abstract}

\section{Opsomming}

Hierdie artikel dien as _ padwyser in die bespreking oor die outobiografiese uitbeelding van die self deur figure van kultuurherinnering wat_funksie is van dubbele bewustheid en dubbele tydelikheid. Daar word aangetoon hoedat twee

1. Jill Arnott uses Spivak's delineation of the two concepts to demonstrate the difference between the "I" that experiences and the "I" who in the retelling (Darstellung) represents (Vertreten) to show the implications for the representation of the relationship between being and knowing as each applies to black and white women (Arnott 1996: 86).

*To cite this article: Kgomotso Masemola (2010): The Individuated Collective Utterance: Lack, Law and Desire in the Autobiographies of Ellen Kuzwayo and Sindiwe Magona, Journal of Literary Studies, 26:1, 111-134 
outobiografieë, naamlik dié van Ellen Kuzwayo en Sindiwe Magona, komplekse ontologiese formasies aan die dag lê waartussen die gaping in die uitbeelding van die self van ervaring en die skrywende self radikaal herhaal word in die veelvuldigheid van individuele artikulering van kollektiewe werking. Die paradoks van individueel-kollektiewe artikulering dui die "gaping" aan wat onstaan wanneer daar in dubbele tydelikheid geskryf word. Hierdie artikel verken dus die "gaping" tussen Darstellung en Vertretung in die veronderstelling dat dit evokatief verwys na die glipperigheid of onstabiliteit van "Waarheid" wat geskryf is vanuit die grense van die grenslyntekste van herinnering in die outobiografieë van twee swart vroue. Want hierdie vroue se skryfwerk loop parallel met - en getuig van - hul sentrale betrokkenheid by stedelike townshipgemeenskappe as maatskaplike werkers en moeders of, as u wil, privaat- en openbare figure. In hierdie gepolitiseerde privaat-publieke dialektiese beweging neem die outobiografieë wat ter sprake is _ Kafkaanse dimensie aan van wat Deleuze en Guattari (1986) deurgaans _ "minor literature" noem. Ten slotte bring die artikel die mate waarin die geskiedenis as _territoriale masjien op die liggaam van die outobiografiese subjek afgeëts word aan die lig, asook hoe dit _ verteenwoordigende krisis skep wat onbewustelik moontlikheidstoestande verskaf - eerder as streng reguleer - vir selfs meer radikale getuienis van die geskiedenis en wording in skryfwerk oor die self.

- _. - "Minors" are heroines.

Ellen Kuzwayo, Call Me Woman (1995: 243)

A multiplicity is only in the AND, which does not have the same nature as the elements, the sets or even their relations. While it may come about between just two, it nevertheless sends dualism off course.

Gilles Deleuze, Dialogues (1987: 57)

In the autobiographical representation of Ellen Kuzwayo's Call Me Woman (1985) and Sindiwe Magona's Forced to Grow (1992), two women traverse a critical gap and/or site of collocation of the "I" of the self and other women, such that the individual experience becomes textually populated with bodies and ideas that project desire in collective utterances and connected fluxes of womanhood. Defined as such, the crisis of representation is also about managing or acting on the individual's articulation of an expressive cause of utterance within an assemblage of women: instead of "speaking for" other women, in which situation Jill Arnott and Catherine Belsey have argued that the subject status of the subaltern woman is denied altogether (Arnott 1996: 85), "[o]ne must, on the contrary, speak with, write with. With the world, with a part of the world, with people" (Deleuze \& Parnet 1987: 52). Only then, I aver, does the collective utterance of the individual writer enter into an assemblage of the abstract machine of struggle and resistance in the townships of Soweto and Guguletu.

Political in nature, collective in its individual utterance, and written in the major language of English, that crisis in Kuzwayo's Call Me Woman and Magona's Forced to Grow qualifies itself as what Deleuze \& Guattari have called a "minor literature" (Deleuze \& Guattari 1986: 12). A minor litera- 
ture speaks with women to a political agenda, and remains collective in its enunciation in the major language. Voices of and visions of Guguletu and Soweto townships are heard, received and transculturated 2 into and from an English major language for autobiography that takes stock of the complex lives of the authors. To be able to transculturate to and fro, or even to reconfigure the subject of cultural discourse, requires addressing the gap between Vertreten and Darstellung as a "crisis" between two components of the autobiographer's semiotic regime. Deleuze explains the first two components as follows:

\begin{abstract}
A general semiotic regime should therefore have a first component which is generative; but it would simply be a matter of showing how an actual assemblage brings into play several regimes of pure signs or several abstract machines, putting them into play in another's mechanisms. A second component would be transformational; but now it would be a question of showing how one pure regime of signs can be translated into another, with what transformations, what unassimilable residues, what variations and innovations.
\end{abstract}

(Deleuze \& Parnet 1987: 52)

This means that when Kuzwayo and Magona slip from individual to collective and manage the "crisis" through a strong coefficient of deterritorialisation of the major language, they are unleashing the heterogenous flux of writing the woman's utterance as part of a rhizomatic machine of women's struggles. Sam Raditlhalo frames this deterritorialisation of the "crisis" of individuation of collective agency as integral to what he terms "the African conception of self and community, and thus the self-conceptualisation of Africans ..." (Raditlhalo 2009: 35). Kuzwayo, for example, recalls that being chosen to play the role of the Skokiaan Queen alongside Sidney Poitier in the film version of Alan Paton's Cry the Beloved Country absorbed her completely but, notably, allowed her and two fellow actresses to make a mark for themselves: "Winnie Ramatlo, Albertina Temba (the lady playing the leading role in the film) and I were a threesome from the Youth Club Association ... we made a mark for ourselves, for the youth clubs and, above all, for black womanhood" (Kuzwayo 1985: 143).3 Here the actual assemblage of three brings into play different regimes of thespians and Youth Club members into another's mechanisms of survival in Soweto.

\footnotetext{
2. According to Mary Louise Pratt, transculturation occurs in a contact zone of colonial encounters, fraught with radical inequality and intractable conflict, when "subordinated or marginalized groups select and invent from materials transmitted to them by a dominant or metropolitan culture" (1992: 6).

3. All subsequent references to Call Me Woman (Kuzwayo 1985) are indicated by page number(s) only.
} 
Yet in the transformational component of the semiotic regime of this kind of play we find that the regime of Youth Club signs - the threesome - can be innovatively translated into a mature consciousness of "black womanhood". It would seem, then, that on the one hand the generative semiotic regime acknowledges the association of women rather than the fluxes of expression in their collective assemblages of enunciation in a language. On the other, the transformative component of autobiographical writing shows how "making a mark" (p. 143) in the capacity of public figures is as good as showing "how abstract machines are themselves capable of mutations, inspiring new assemblages" (Deleuze \& Parnet 1987: 52). In the same vein, we need to question whether her citation of struggle stalwarts stresses association or identification. To do this we need to understand the beginnings of her community role as an aspect of her black womanhood. From what Kuzwayo remembers as a nominal role at the second conference of the National Council of African Women, held in Bloemfontein in 1938, she was to be elected secretary of the local branch of the Thaba Nchu branch of the NCAW (p. 103), never looking back ever since because of powerful female political figures she met at the conference: Charlotte Maxeke, the first National President of NCAW, and Minah Soga, the first General Secretary of NCAW and intellectual force behind deliberations at the All African Convention held in the summer of 1937 in Bloemfontein.

The momentum of Kuzwayo's community involvement gathers pace in Soweto, where, she confides: "In the struggle to settle down after the shocking experience of my marriage, I immersed myself in some of the events taking place in my community, such as youth work training and running youth clubs in Pimville and Orlando" (p. 139). All this time Kuzwayo's family constellation, together with its projections of negative and inferior black femininity, is reconfigured in the course of a transformation of subjectivity within an assemblage of black womanhood. In the family constellation's possibilities of oppression are gathered assemblages that enter the abstract machine of the black community's struggle; for women who "escape" the family do that only to the extent that they remain attached to negotiating its institutions through unconventional single motherhood or womanhood based on responsibility to others in the community.

It is in this context that Kuzwayo asserts at one point or another how impressed she is by girlfriends who "later found their life-partners and settled into family life in different places" (p. 99). She counts amongst these Norah Fries and Epeinette Moerane (p. 87). The latter went on to marry Govan Mbeki, an outstanding leader of the African National Congress (p. 100). Through this marriage, which translated into a redoubtable alliance in a resistance-machine, Epainette grew in stature, as did her role in the community. Epainette Mbeki is the mother of Thabo Mbeki, the former President of the Republic of South Africa. 
The kind of family that Kuzwayo envisions and admires has the dual capacity to reterritorialise the fluxes of expression that underscore womanbecoming while, at the same time, it can deterritorialise the same fluxes into combinations and continuums of intensities into a machine assemblage of desire for the liberation of the oppressed African majority in general and women in particular. This "emergent" family as expressed in the married life of the likes of the Mbekis represents, in the face of apartheid, a problematic function; for we have a case of Kuzwayo's response to its torture and illness after her miscarriage on the one hand and Epainette Mbeki's new formulations of woman-becoming through the assemblages of motherhood, wifehood and black womanhood on the other hand. Deleuze insists:

We must define a special function, which is identical neither with health nor with illness: the function of the Anomalous. The Anomalous is always at the frontier, on the border of a band or a multiplicity; it is part of the latter, but is already making it pass into another multiplicity, it makes it become, it traces a line in-between. This is also the "outsider".

(Deleuze \& Parnet 1987: 42)

The anomalous function of what I call the emergent family places both husband and wife, man and woman, parent and child on the frontier of the struggle against oppression. The woman is always passing on to another multiplicity outside the family band, the mother traces a line of flight between the family and black womanhood. The different states are blocs of becoming.

Kuzwayo's writing therefore records not only defeat but meaningful struggles, carried through the anomalous function of the emergent family. As an assemblage the family has two faces both in terms of textuality and experience: the oppressive aspect that reterritorialises through the socius of apartheid and patriarchal edicts of "appropriate motherhood", as well as the possibilities of constant deterritorialisation and woman-becoming. It is only a pity that the distinction is always made in retrospect, after a divorce or a complete nonstarter of a possible marriage in Magona's case. There is a distinct sense in that assemblages of desire are proscribed by the law responsible for the formation of subjects in South Africa. Magona discovers this when she looks at her husband's file at her Cape Town City Council workplace:

In 1966 my husband, I found, had been endorsed out of the area. I discovered he had been a $10(1)(d)$ _ a migrant labourer with an a nnual contract who had to go home each year. I was $10(1)(b)$ _ one who had legal rights to live in Cape Town. I held that file for the longest minute I had ever known while thoughts raced through me. Then I put it back. And walked away. We never really had a chance, I realised. We were fools to have married. We had not an inkling of what we were pitting ourselves against. Gross lack of awareness had made us naturals for our break up. Indeed, we had not known 
we were pitting up ourselves against anything. Definitely not against the state, the mighty government.

(Magona 1992: 90)

Kuzwayo and Magona are aware of the role of the apartheid State in the breakdown of communities, demanding interventions at community level. Kuzwayo, however, is acutely aware of the personal failings of her first husband from the moment she runs away from her Saulspoort home. Magona sees the failing of her husband as symptomatic of personal ignorance of how apartheid functioned to (dis)organise private family life. The one thing immediately common to them is that the woman subject constructed through discourses of apartheid is repeated negatively (in denial of stereotypes) and then in the middle (in leveraging the power-effect of the emergent family and the community resistance to apartheid) in order to engender a rendition of multiplicity whereby the loss of a husband does not constitute lack but an opportunity for radical agency.

Of necessity and in principle, becoming goes beyond merely negating the apartheid logic of the stable object of control as well as cultural discourse's construction of a woman as a partial object growing out of the family tree, as it were. The (dis)continuity of fixed affiliations with men (both Kuzwayo and Magona have had to live without husbands as a result of either desertion or divorce) also means that sharing the same lot of discrimination does not necessarily mean that the emphasis should be on identification either. Repetition here is neither positive nor negative but situated in between two discursive formations and, as such, located on the edge of both. There is in the foregoing sense a "minor-becoming" in reference to which I would like to explain the said autobiographies in terms of Deleuze's concept of woman-becoming: "A minority never exists ready-made, it is only formed on lines of flight, which are also its way of advancing and attacking. There is a woman-becoming in writing" (Deleuze \& Parnet 1987: 43). Thus, Kuzwayo's and Magona's residence in the gap or, rather, between the two logics of gender and racialised class, between patriarchy and apartheid, between family and society, irrevocably constructs a plane of being which cannot be reduced to one category of existence or the other: lines of flight, lines connecting different natures, multiple positions, all of which are problematically represented in the Darstellung/Vertreten gap in writing, trace an advance in the collective politics of self-affirmation. Being in between is akin to being - as Magona's title suggests - forced to grow. Such is the condition of minority-becoming in writing: "Every multiplicity grows from the middle, like the blade of grass or the rhizome. We constantly oppose the rhizome to the tree, like two conceptions and even two different ways of thinking".4

4. One finds this remark early on the prolegomena on multiplicity in Deleuze \& Parnet (1987: viii). Here Deleuze anticipates his later discussion of "the 
When Magona renders her growth as a survival account of being a lone mother in Guguletu through autobiographical writing we witness her becoming through her relationship to a family which is more like a tree: there are rhizomes of escape from marriage while being connected to it. Her woman-becoming passes through points of wifehood and motherhood, across the shifting matrices of familial configurations. If anything, the latter constitute a site of reinscription of identity - based on the transformative component of a selfing semiotic regime. Magona does not belong to the two points but becomes in the middle. This is amply reflected in her writing. Her literary style involves the transculturation of Xhosa lexical items in such a manner as to make the major language of English follow new routes of meaning, further from clear linguistic or cultural roots of neither English nor Xhosa. As in a "minor literature", this makes for the "strong co-efficient of deterritorialization of a major language" (Deleuze \& Guattari 1986: 16) as well as the discursive formations of identity-making. These are therefore not simple language games imagined through semiotic regimes but a deterritorialisation that guarantees an engagement of the history of the body politic through writing. While Pumla Dineo Gqola correctly ascribes primacy to a womanist5 reading of writing such as Kuzwayo's on the strength of "a self-reflexive affirmation of subjectivity", her observation that Kuzwayo is one of those who "write their lives with and through the lives of other black women" (Gqola 1996: 47) lends itself to both woman-becoming and the collective thrust of a minor literature. Writing not necessarily on her account, Magona outlines at some point how deceptive a woman who trades on men's weaknesses can be when she is drawn into fruitless and illegal marijuana selling. In this example, the woman who purports to be Magona's saviour through this enterprise convinces her to gather the exorbitant advance outlay because "[i]t's just that that dog, Lizo's father, did not give me anything this week. Otherwise I would be taking all this stuff by myself" (p. 7).

between" as becoming, and he borrows the grass image from Henry Miller's Hamlet, quoting: "Grass only exists between the great non-cultivated spaces. It fills in the voids. It grows between - among other things. The flower is beautiful. The cabbage is useful, the poppy makes you crazy. But the grass is overflowing. It is a lesson in morality" (Deleuze \& Parnet 1987: 30).

5. According to Lindsay Pentolfe Aegerter,

[w]omanism, a philosophy that has "wholeness" and healing for all Black peoples as its aim, offers a dialectical paradigm that does not dichotomize Southern African experience into pre- and postcolonial periods, Western and African cultures, oppressor and oppressed, colonizer and colonized, Black and White, men and women ... seeks to revise and to retain African traditions [by] resisting and utilizing Western epistemologies, economies and ontologies.

(Aegerter 2000: 67) 
The suggested disavowal of the binary mode confirms womanism's refusal to dichotomise men and women, or even black women of higher status and their poorer counterparts. Gqola confirms this woman-becoming when she urges caution about Kuzwayo's writing, especially where she quotes the exhortations of Charlotte Maxeke, the first president of the National Council of African Women, who insisted that organisational work is not for themselves but for "your people" (p. 103). Clearly Kuzwayo refers to Maxeke in order to extend herself beyond an individual expression of the desire to be liberated and committed to struggles of the community. According to Gqola, "[w]riting a story about one's life, where the writer is the main focus, makes appeals and claims for exceptional status. These women, however, choose to relate the story of their lives by merging their lives with the lives of women in their predicament" (Gqola 1996: 52). In these circumstances, it is apt to consider the parameters, however much shifting, of the said woman's predicament as a site of contestation and engagement, and of transculturation and upliftment, within an assemblage that confirms its priority over the self-assured, insular plenitude of an oppressed black female subject. Writing a story about one's life, then, uncannily confirms what Deleuze says of the basic unit of collective writing in any instance:

The minimum real unit is not the word, the idea, the concept or the signifier.
It is always an assemblage that produces utterances. Utterances do not have
as their cause a subject which would act as a subject of enunciation, any
more than they are related to subjects as subjects of utterance. The proper
name does not designate a subject, but something which happens, at least
between two terms which are not subjects, but agents, elements.

(Deleuze \& Parnet 1987: 51; my italics)

Between being a subject of enunciation - whose collective assemblages of enunciation in a language as flux of expression are fixed in content; and a subject of utterance - whose heterogenous components continuously transmit effects to one another - inheres a multiple subject whose status as an agent writing across an assemblage bespeaks movement of agents and elements. To write as Sindiwe Magona does is to chart a woman-becoming in the middle rather than the travails of the subject as designated by the proper name. The deterritorialisation of what seems to be a stable subject and proper name in the major naming language attacks the law of invidious discrimination against the woman. Lines of flight 6 to other women within the black assemblage are reflected in the flights of meaning from enunci-

6. Constituting a multiplicity, or rather a being-multiple as opposed to a beingone as a subject, "[t]hese lines are true becomings, which are distinct not only from unities, but from the history in which they are developed"

(Deleuze \& Parnet 1987: ix) 
ation to utterance, from the individual to the collective: woman-becoming expresses itself in the transformational fluxes of an ever-changing womanhood in writing.

The result is a discursive migration from object to subject, then from the doubly proscribed subject of apartheid and patriarchy to a doubly inscribed subject of cultural discourse and collective utterance. For instance, Magona describes herself as idikazi ("an unmarried female") and umabuye' ekwendeni ("a returnee from wifehood"), both terms being understood on the basis of not being directly translatable, in a cultural sense, from Xhosa to English except only in a loose sense of a "has-been", which "still does imply some prior accomplishment; being that which one no longer is: a previous, if lost, glory" (p. 1). Such tone and facility allow for a critique in the major language of English. It becomes apparent when she mockingly glosses the word idikazi according to a 1918 print of Reverend Robert Godfrey's $A$ Kaffir-English Dictionary, which does not only define the word as referring to "an unmarried female" but also, according to Magona, "further enlightens us, this is 'a term of reproach to all women who are husbandless'” (p. 1). Her utterance, bringing into play multiplicities and, in the course of it, other women as it invents new assemblages of woman-becoming, new productions of meaning around being husbandless.

Although it may seem as if Magona complains that English as a major language has no equivalent for a man with children but no wife (p. 2), the possibility of utterance in the major language allows her fully to express her relationship to women and familial relations in a way that describes the cultural subject-constitution of women as commensurate with political appropriation of a black subject. To be a "husbandless" mother in Cape Town and unemployed black person poses a special political challenge for her, necessitating a much broader approach to the understanding of, and inveighing against, the two logics of laws that regulate her life: gender, racism and capitalism. Magona's writing is not only written from the margins, from the borderline: it underscores becoming in the middle, between the margins and the inscribing socius of the family institution. Movement of becoming is inscribed within a gap that Catherine Belsey identifies as existing between the "I" of utterance and the uttering "I" (Arnott 1996: 85). A different subjectivity of idikazi emerges, caught up within - and reinventing from between - the territorial machine of apartheid and familial discourse, into one of a woman subject who is not morally loose but always moves with transformational fluxes of becoming.

Negotiating not only a selfing regime that goes beyond escaping the squalor of Guguletu to New York but also renegotiating familial and communal constraints, this autobiography charts the lines of flight across the discursive formations of blackness and womanhood. Magona, like Kuzwayo when she animatedly speaks of her Mother and her Aunt Fanny as strong characters who mould her behaviour (p. 66), looks to her mother and 
other women in Guguletu in order for her to eke out a living in a situation where "South Africa must surely hold the dubious honour of having legally created unemployment" with its job discrimination laws (p. 3). These women, though oppressed, are harbingers whose attempts at liberating themselves from poverty and gender oppression do not necessarily mean abandoning motherhood or mothering practices. Like Kuzwayo, Magona constructs her selfing through a woman-becoming that hinges on the public upward mobility of women. She refers to a time when a Mrs Mbombo points out that motherhood is not an obstacle per se:

"Sindiwe, don't leave school. Finish high school. Do your matric." This suggestion, bordering on lunacy in my opinion, came from Mrs Mbombo. Several years older and married with one child, she was a nursing sister. Later she would resume her own studies and become a medical doctor (one of probably less than ten female doctors in the whole country at a time).

This is not merely citation or identification but a rhizomatic connection with other women whose concern with community responsibility begins within the family assemblages of motherhood. Magona's Forced to Grow and Kuzwayo's Call Me Woman reflect this intertwined sense of being-forOthers, too. More than that, she represents herself as one of the women who feel angry before she takes "the first healing step towards my own free state of being" (p. 16). This, of course, must be understood in the light of the fact that, for one thing, Magona shares a strong conviction: "Need is a terrible thing and when it engulfs the young, the very young, the most vulnerable, it eats into one's very heart, especially the heart of a mother" (p. 7). For another, in a symbolically significant moment, she allows herself to incur the slur of being an idikazi when she let her wedding ring run into the sea:

Looking back I now know that I had begun to "let go". I had embarked on the long journey that was to be the rest of my life, travelling light, sans husband. The act of letting the ring go was deliberate, but it was prompted, suggested if you will, by the workings of the waves. I am famous for hoarding, for stinginess and total inability to splurge even on myself. What possessed me then, that day, to commit an act of such reckless abandon? I know I felt very satisfied with what I had done.

However much "letting go" seems liberating, since she owes her being right there in the waves, being in full contact with nature and therefore out of the manacles of patriarchal culture, she remains connected to her women friends. This is a fact she acknowledges without ever pretending that she is wholly feeling the transformation into a repudiation of womanhood or woman-becoming: she is a mother still. Sam Raditlhalo elucidates the paradox of "letting go" thus: "the strange matter of self-invention and its myriad 
stages is simply that it cannot be accomplished through the shedding of an identity" (Raditlhalo 2009: 44). In motherhood lies her responsibility to herself and the community, too. What with her lament about the dissipation of the glue that held the community together during the government's dispersal programme (p. 14), i.e. the social capital deriving from the family. She also acknowledges the implication of being an idikazi in the whole scheme of all things political and cultural.

Magona's writing, such as it is, represents traces of "lines of flight" that reconfigure the construction of a subject by the scripts of the apartheid socius and patriarchy. In short, that "gap" of self-representation does not only bear witness to the instability of "truth" of experience but also reflects the multiplicity that inheres in writing. According to Deleuze, "[i]t is possible that writing has an intrinsic relationship with lines of flight. To write is to trace lines of flight which are not imaginary, and which one is indeed forced to follow, because in reality writing involves us there, draws us in there" (Deleuze \& Parnet 1987: 43). "In there" is the Belseyan gap of utterance between which reinscription is an act of becoming; it is occupied by an agent of history, not merely its witness. When writing "remembers" in such a way that subject positions are differentiated not only on a temporal gap of past and present, Vertreten and Darstellung, subject of enunciation and subject of utterance, it becomes clearer that the gap between mother and wife allows for the representation of collective interest through a series of repetitions. Repetitions of role models are not merely to repeat the achieved feat or negate the stereotypes of weak femininity. To repeat in writing is to problematise reportage of the historicity of female subjectivity: Magona's autobiography revises and contaminates the discursive construction of stable motherhood as an object rather than the subject of cultural discourse:

The censure came from women as well as from men. Their agreement about
the correct behaviour for women with children chilled me to the marrow.
Married, divorced, widowed and single mothers were lumped together.
Mothers, it was clear in the minds of the vast majority, had no business being
anything else. But I had dreams yet. My alarm grew with the discovery that I
was expected, calmly and mother-like, to await old age and death.

Magona's awareness of the complicity of women, "husbandless" or not, in the patriarchal subject-constitution is one way of explaining her willingness to break ranks with them as she pursues her dream of emancipation through an immersion into American graduate education in an Ivy League College. It allows her to rationalise her decision to leave her three children against the cultural logic of femininity: "The decision to leave them when I did was mine. But I had been pushed to it" (p. 195). Although this decision to leave children is also evident in Kuzwayo's Call Me Woman, it is much more difficult and fraught with greater hardship, especially considering that she 
leaves her children behind "pretending that they did not matter" to her ( $\mathrm{p}$. 131), and that in the strength of her resolve to leave she spends the night sleeping in a graveyard. Like Magona, before she embarks on a journey she declares: "Not once did I shed a tear on that journey, as there was no time for self-pity. This time I was not forced out of my 'home'; on the contrary, the decision was mine. All the same, and perhaps I am wrong, I was pushed out psychologically" (p. 131). Taking her cues from Desiree Lewis, Carmela Garritano has noted with concern the equation of womanhood with motherhood in Kuzwayo, adding that the construction of such womanhood "stresses women's self-denial and inferiority" (Garritano 1997: 59). Although Kuzwayo also went to New York as a representative of the Young Women's Christian Association (YWCA) congress in 1961, and Magona continues to do sterling work for the United Nations, their commitment to local issues - ranging from the rural to the urban setting and to the empowerment of women - defines the interest of their writing. In Kuzwayo's Call Me Woman, we find that she heads for Johannesburg, away from her Saulspoort home, as she escapes from a torturous marriage that degraded and humiliated her - a scourge she has "come to realise is suffered by many wives the world over, within different races, cultures and religions" (p. 124). The collective utterance beyond her own situation as a woman straddles a universal plane to include all women, within and without South Africa. Her being in that situation brings to the fore the multiplicity to which she belongs. As Deleuze would explain: "A multiplicity is never in terms, however many there are, nor in their set or totality. A multiplicity is only in the AND, which does not have the same nature as the elements, the sets or even their relations" (Deleuze \& Parnet 1987: 57). In this way her multiplicity lends itself to a womanism that is irreducible to race, religion or nationality.

Yet, to articulate that collective utterance of multiplicity in her immediate surroundings, Kuzwayo has to take stock of the familial constellation. Her autobiography, recasting the family in a sober act of remembrance, was to be a book that asserts that multiplicity through lines of flight whose focus of unification is based on the decentring of the family, particularly in the sense whereby the institution itself is reconstituted on the basis of selection and rejection of elements. Abusive acts of a husband, who is part and often head of the family, are not the sum of family life. Committed motherhood cannot be shaken off by the constant knocks at the hands of Ernest Moloto, her abusive first husband. Besides, her utterance places her among other women, producing the collective effect of a "minoritan" discourse that writes back against the patriarchal subject-constitution of femininity within the family:

Now that he is dead, I feel he has missed reading in this book my considered assessment of what our six years of married life together were to me. The violence, arrogance, meanness and downright selfishness which prevailed in 
our home eclipsed all the positives of his intelligence, his well-built structure and handsome appearance, his financial acumen - even if it was at the expense of his family. The atmosphere in that house left me no alternative but to leave, and in that way to save myself for myself as well as my two sons.

(p. 127; my italics)

Kuzwayo makes bold to entwine the vision of saving herself to the survival and security of her two sons. This does not in any way mean that her motherhood ratifies her loss of subjecthood. Instead, the stress is on resilience in the wake of the torture she experiences within the family. A critic such as Garritano has all too readily dismissed the image of the "strong black woman" as "subsumed by the general ideology of its subtext, a set of restrictive conventions about motherhood that shape Kuzwayo's experience and her interpretation of experience" (Garritano 1997: 59). I disagree. Her marriage does not define her existence, sour as it comes. What is of concern to her was that she had no immediate and workable plan to keep her sons as she makes her next move. Recognising this dilemma in the fresh aftermath of her miscarriage, she boldly resolves:

As I lay in bed, I pondered seriously about what my next move should be when I recovered. My experience left me no choice but to return home to my father. That is when I decided to save myself for myself, and for my two sons. By that time the façade of putting on appearances had lost its meaning. It was replaced by hurt, humiliation and total frustration, but it did not kill my desire and determination to live my life to the fullest, given another opportunity.

$$
\text { (p. 125; my italics) }
$$

As Kuzwayo contemplates her self-saving move, she considers it a task inextricably intertwined with saving herself for her two sons. This responsibility of motherhood she cannot eschew, it seems, until she comes to a point of individuation at her in-laws' house in Legkraal. She reluctantly leaves her sons in the care of their paternal grandmother, her mother-in-law, in order to save herself. Likewise Magona is faced with a similar situation when she resolves to finally leave her children so that she could pursue her master's degree programme at Columbia University in New York in 1981 (p. 192). At her send-off party questions of the responsibility of motherhood arise: '“How can you leave the children?' asked a friend, forcing me to confront a question I had been dodging for a long time. How could I leave the children? I know women who have foregone opportunities to go abroad because they 'couldn't leave the children alone'” (p. 197).

Similarly Kuzwayo's autobiography seems to begin in medias res, with a letter from Debra Matshoba, held in Johannesburg Fort prison under Section 10 of the Terrorism Act (p. 4). However, Kuzwayo hastens to add that the admirable qualities of special courage and strength surface only after she is 
"married and the mother of a lovely, bouncy boy aged two" (pp. 4-5). What is even more significant is that "[ $\mathrm{t}]$ hese qualities surfaced at the time of her detention when she was no more Debra Matshoba but Debra Mabale" (p. 4). Marriage, motherhood, and womanhood combine into a redoubtable combination that ironically inhabits a space that negatively repeats phallocentric domestication in order to heighten its resistance to the family-as-passive object of apartheid.

The "emergent family", as I prefer to fashion it in these circumstances, distinguishes itself from the conventional family insofar as it is a site of construction of desire for a woman-becoming whose collective utterance is capable of revolutionary public participation. Thus, the "emergent family" allows for a plane of construction on which each partner, particularly the black woman in Call Me Woman, can act on the desire to resist the laws that organise subject formation in South Africa. Deleuze tells us that "desire only exists when assembled or machined. You cannot grasp or conceive of a desire outside a determinate assemblage, on a plane which is not preexistent but which must be itself constructed" (Deleuze \& Parnet 1987: 96).

It is axiomatic that the family here is a site where such desire is assembled, zoned and homed in, which provides grounds of immersion into coded partriarchy - a form of exposure into the logic of desiring-production that leads to the implosion of the familial structure without eroding filial ties. From the breakdown of marriages of Magona and Kuzwayo arises a group subjectivity, partnerships of women in the struggle for livelihood and recognition. A discursive migrancy from a narrow conception of female subjectivity is hereby asserted. The course of this migrancy, such as it is, charts a "minoring", a woman-becoming, a collective utterance, a movement from motherhood into black womanhood, into the assemblage that enters the abstract machine of African nationalist struggles. Once again, it is Deleuze who notes: "Since every assemblage is collective, is itself a collective, it is indeed true that every desire is the affair of the people, or an affair of the masses, a molecular affair" (Deleuze \& Parnet 1987: 96).

Forced to Grow in particular evinces those discursive migrancies that make the family, or rather the breakaway from its configuration of husbandwife partnership, another serious feature of an assemblage in terms of the autobiographer's ambivalence towards it. The movement here is from being the "body without organs" in relation to the patriarchal family and the apartheid State into being-woman on terms that subvert the prescriptions of the apartheid territorial machine. In the case of Magona it is always in relation to the revolutionary drives and the imperative of the individuated utterance. Magona follows in the footsteps of Kuzwayo as she reinscribes her womanhood within the collective assemblage of "black womanhood" as espoused by the National Council of African Women (p. 174).

Is it possible, then, that what Pumla Gqola, in the fashion of Layli Phillips, explains as womanism's recognition of the absolute necessity to speak from 
and about the black experiential location "and not someone else's" actually informs utterance of fluxes of expression in Kuzwayo's and Magona's writing? In other words, does a "minoritan" becoming in writing allow for a collective utterance that includes a focus of unification between womanhood and blackness or, more specifically, Africanness? This question harks back to recent discussion about the theoretical possibilities offered by an acknowledgement of what Paul Gilroy framed as the specificity relating to the complex internal divisions in particularity of class, sexuality, gender, age, ethnicity and political consciousness: "The themes of nationality, exile, and cultural affiliation accentuate the inescapable fragmentation of the black subject. This fragmentation has recently been compounded further by questions of gender, sexuality and male domination which have been made unavoidable by the struggles of black women ..." (Gilroy 1993: 35).

This suggests caution about blind application of postmodernist feminist categories of analysis. It is with this in mind that I offer a corrective rereading of such application as well as of Kuzwayo's novel hereunder. This is especially necessary given that the particularity of womanhood and Africanness as part of the internal division of autobiographical subjectivity requires a reconciliation between the specifity of womanism's speaking from one's experiential location, on the one hand, and a rhizomatic connection to "someone else's" mode of writing, however much deterritorialised. The reconciliation is both difficult and inevitable. The intercultural thrust of autobiography, as we have seen in the case of Mphahlele and others, is evenly matched by constant referrals to and transculturation of the transnational archive of cultural memory. At a literary theoretical level, at which womanism and my discussion of Deleuzean woman-becoming is handled, a challenge for uninformed postmodern feminism awaits. This also has a history.

Until almost four decades ago, when James Olney first published Tell Me Africa: An Approach to African Literature, the question of the relationship between a non-African readership and the "especial Africanness" of African self-writing remained muted (Olney 1973: 52). It is now crucial to raise this spectre once more, interrogating the premises from which Carmela J. Garritano draws up perceived categories of paradoxes and tensions in Ellen Kuzwayo's Call Me Woman, with the objective of arguing that Garritano all too readily imposes skewed feminist imperatives that are quite at odds with the local political commitments of Kuzwayo as a public figure. There is every indication that Garritano's postmodern "deconstruction" - an exercise she mismanages by her perfunctory lacing together of disparate postmodern concepts - of Kuzwayo's autobiography will find everything it imposes on the novel: phallocentricism, monolithism, contradiction, paradoxes, and suchlike (Garritano 1997: 62) - instead of fluxes of expression of content and desire or, indeed, heterogenous combinations. She basically ignores the gaps identified by Spivak, Arnott and Belsey, an awareness of which could 
have successfully lent itself two distinctions: between the subject of enunciation and the subject of utterance, and between the generative and transformative aspects of the semiotic regime of writing. Basically, the analysis questionably proceeds by tracing fault-lines. In her ardent fervour to bring to an obviously realist text postmodern subversion and reinvention strategies, Garritano is quick to separate the author's deliberate construction of, or participation in, a discursive practice which, I have argued, expresses a collective utterance rather than mere enunciation:

Call Me Woman ... reveals its own textuality as it slips beneath its author's control. It is a text vitiated by contradictions and intersections. Kuzwayo seems to struggle between mythologizing a pre-colonial, rural and pagan South African past and admonishing the remnants of such a past, between supporting the tenets of Christianity and recognizing Christianity's complicity in apartheid, between praising the power of the community and extolling the virtues of individuality, and finally between defining women who act like me as subjects, and on the other hand, relegating women to positions of objects.

(Garritano 1997: 63)

It would seem that Garritano expects a singular denunciation of what Kuzwayo calls "a code of traditional moral values" (p. 16) or, if not, expects that Kuzwayo must be silent on the virtues of pre-colonial life prior to the encroachment by settler-colonialists. If ever there is a contradiction there, it is resolved by time-lines and deliberate shifts from pristine rural life to forced removal or appropriation of such land through invidious apartheid Land Acts. Kuzwayo does well to express these shifts through individual acts of "selfing" which, by and large, attest to growth, self-actualisation, attainment of wholeness through fragmentations and achievement. Hence it is that Kuzwayo does not hesitate to speak of "great mothers of South Africa" (p. 23). To speak animatedly and unapologetically about such women is to point to signposts already set by harbingers in the community. It would seem that the simple idea does not sit well with Garritano. She is not alive to the fact that the community is more than the sum of its individuals, that it is the recognition of the barriers that women have to surmount to fully belong to achieving groups, and that as women who are "like men" participate meaningfully in healing the apartheid-infested society they live in. Blind to the interconnectedness of the woman's assemblage as it enters the resistance abstract machine as its male "outside", Garrittano proceeds in a bland misappropriation of Sidonie Smith's postulations:

Kuzwayo speaks like a man. The female autobiographer who occupies such a position, according to Sidonie Smith, "becomes essentially a 'phallic woman"', an artificial man-made product "who desires the cultural recognition that flows to her as a person who embodies male-identified ideals" ... she 
earns this recognition at the expense of all those women who remain at the negative end of the divide.

(Garritano 1997: 60)

Whereas it is clear from Kuzwayo's involvement in the life of the community, especially in initiating training programmes for the National

Council of African Women, it is clear that whatever the rate of the resulting success there is no strict divide between negative or positive pole but a continuum. Where "women on the other side of the divide" do not feature as prominent, it is because Kuzwayo extols the virtues of those who made it in a man's world. Perhaps such "participation" can be faulted when it "relegates women to the position of objects" (Garritano 1997: 63); yet there is much to suggest that Kuzwayo's autobiography constitutes womanbecoming, a process that involves rhizomatic alliances and co-functions across gender. Quite significantly, I find in Kuzwayo's Call Me Woman the wisdom of Deleuze's clarification about women who force themselves to write like women: "Woman is not necessarily the writer, but the minoritybecoming of her writing, whether it be a man or a woman. Virginia Woolf forbade herself 'to speak like a woman': she harnessed the womanbecoming of her writing all the more for this" (Deleuze \& Parnet 1987: 43). Being a self-proclaimed postmodernist, Garritano should be familiar with this concept. Perhaps the assumed simplicity and naïvety of an African writer in Kuzwayo does not warrant for such deployment. Instead, she elects to complain about Kuzwayo's routine submission of a list of achievers rather than pursuing a proper feminist agenda:

The paradigm remains the same. We are still locked into a humanistic understanding of totalizing identities that erases the multiple subject positions occupied by the women about whom she writes. Her public story of public lives lionizes the political and social successes of black women at the expense of disregarding other aspects of their lives and ignoring the import of class. Kuzwayo leaves us no space out of which we might imagine other ways of conceptualizing female subjectivity.

(Garritano 1997: 62)

What "other aspects" is Garritano talking about? Does Kuzwayo not announce at the outset that these are "mothers of South Africa" first and foremost, that is, before they are lawyers and doctors? Does Kuzwayo not record her own domestic breakdown and how she had to move from an oppressive domestic setting to support her public career role? Garritano has clearly thrown scepticism at the lionising tendencies in Kuzwayo, as if these were not part of raising the consciousness of women who are labouring under a "false consciousness" or ideology of accepted inferiority. If anything, class and consciousness have a direct relationship. It might not be explicit to Garritano who, ironically, wants class to be a totalising identity 
for women. Coming from a postmodernist this is very surprising. We would have expected a disavowal of a generalising catch-all identity. It would have been instructive and honest for her to also acknowledge that Sidonie Smith also defines "the autobiographical manifesto as follows: 'Purposeful, contentious, the autobiographical manifesto contests the old inscriptions, the old histories, the old politics, the ancient regime, by working to dislodge the hold of the universal subject through an expressly political collocation of a new 'I'” (Smith 1993: 157).

What happened to the multiplicity for which Garritano clamoured? Garritano's is doublespeak, the hallmark of double standards which, ironically, remains oblivious to the double face of black womanhood's collective assemblages of utterance. In similar fashion, Garritano puts blinkers on the fact that all the other women whose successes that Kuzwayo records actually supplement her story as a woman activist. Kuzwayo is not stuck in the eternal "I" of autobiography; there are other women, involved at other levels of struggle, with whom she narratively establishes a co-functioning within the assemblage of "black womanhood". "This was Mary," she says, speaking of Mary Xakana (p. 248), or "This was Phyllis Noluthando Mzaidume born Maseko" (p. 165). Obviously the upward mobility of women as a social group is important to Kuzwayo and can be read as feminist or, as Garritano prefers it, "a humanistic feminist position" (Garritano 1997: 60). The contributions that these women make to society, every achievement they attain, is part of a tapestry of shifting identities, a multiplicity of woman-as-mother, mother-as-provider, provider-as-nurturer, nurturer-as-doctor, doctor-as-role-model, etc., until it all comes back full circle to black woman as proactive agent in history. This, if anything, explains the multiple public figures that populate the narrative of Kuzwayo as a public figure. Their successes are hers, and their histories intermeshed with hers _ all in one autobiography that implicitly or explicitly spells out her intersubjectivity with women in a similar struggle against the domestic obstacles Kuzwayo suffered privately, against the social stereotypes into which women are pigeonholed, and against the prejudices each and every one of these women overcome to become respectable and politically effective public figures. These are all differential histories, instances of the individuated collective utterance and/or agency, not what Garritano misconstrues as Kuzwayo's perpetuation "of history as the story of homogenous individuals, races, sexes, and classes" (Garritano 1997: 62).

It would seem that Garritano expects a retreat to the particulars of private space when she doubts the ideological authenticity of the narrative of a black woman public figure. Yet that might well be an unfair suspicion of a scholarly reading of autobiography. At best that scholarship is not free from interest; at worst it might be fraught with gross misreadings. Consider for instance the fact that in her conclusion Garritano asserts: "[P]laced within a historical framework ... Kuzwayo vehemently defends the bourgeois, 
Christian values of her childhood. At the same time, she is influenced by Black Consciousness ... its belief in a homogenous black identity, and its romanticization of a pre-colonial Africa" (Garritano 1997: 64). First of all, this narrow reading of history in a teleological fashion not only departs from the postmodern tenets of her analysis but calls to question Garritano's understanding of what counts as the immediate relevance of situating - not romanticising - the past in order to deal with its continuing legacy in the current apartheid malaise. Says Kuzwayo:

I ended up saying, for me, Black Consciousness was an institution, a process whereby blacks in South Africa were beginning to take a serious look at themselves against the perilous political plight of a history of close on 350 years, and to find a way of redeeming themselves from that crippling situation. "This is our dilemma," I finished. "I believe in Black Consciousness."

There is at once a recognition of a powerful undercurrent of African humanism in the novel, which turns inward into itself through the urban and the rural, and a need to construct assemblages of resistance on political and cultural fronts. The Bapedi dance of which Makeba in Makeba: My Story (1988) excitedly spoke in her autobiography, and the famo dance of the urban migrants from Lesotho in Mphahlele's The Wanderers (1973) also named as famo and timiti in Kuzwayo (pp. 29-30), have a rural counterpart in the lebollo dance by circumcision initiates (p. 71). In both urban and rural settings, however, even the transculturation of educational, cultural and religious values is everywhere evident. It is in the light of this that Kuzwayo is proud of educated black people, including the prominent lawyer and political leader Nelson Mandela (p. 139); Principal of Fort Hare University, Professor Z.K. Matthews (p. 86); medical doctor and activist Dr J.S.

Moroka (p. 84); Tuskegee College (USA) social work graduate and community leader Violet Sibusisiwe Makhanya (p. 90); outspoken Anglican Bishop and Nobel Peace Prize winner Desmond Tutu (p. 260), and so forth.

From time to time, we have heard Kuzwayo assert ubuntu in different idioms such as "motho ke motho ka batho" (a person is a person because of others, or a community is the sum total of its individual members) which essentially calls for the practice of solidarity. If ever Garritano sees fit "to place Kuzwayo within a historical context" (Garritano 1997: 64), then she must factor in, not elide, apartheid as a political, social and economic system against which oppressed South Africans rallied by using diverse strategies, including writing one's invisible self into history or - in the case of black women - etching their own particular signature in the record of broad struggle. According to Elleke Boehmer, Kuzwayo's Call Me Woman is a groundbreaking autobiography that marked a very important development "in the 1980s, during the years when government oppression was at its height" (Boehmer 1995: 225). The historical context within which Kuzwayo 
writes is accounted for by Boehmer in a way much unlike Garritano's, a fact that cannot be simply chalked down to either Garritano's blithe ignorance or postmodernist rendition of it. In the place of contradiction, Boehmer observes a complementary duality of role: "On the one hand, black South African women struggled to withstand the system of multiple discriminations that was apartheid. On the other, they tried to stake out a place for themselves in the always still male-dominated liberation movements. The autobiography allowed them to give shape to an identity grounded in these diverse experiences of endurance and overcoming" (Boehmer 1995: 224).

It seems apparent that telling the stories of all those women who have excelled in political and public domains is a powerful statement of what Boehmer calls "distinct actualities" (1997: 224), of what I earlier on described as differential histories of self-actualisation. However, Garritano chooses to endorse Desiree Lewis's argument that the restrictive ideology of Call Me Woman's subtext relies on a "construction of womanhood that stresses women's self denial and inferiority" and "equates her womanhood and motherhood". This is a tad surprising, given that Garritano herself has on the same page made specific mention of the fact that Kuzwayo was forced to leave her sons and, I might add, so seek her self-definition outside of the yoke of marriage, between selfhood and motherhood.

Garritano is contradicting herself here, or simply refusing to take her arguments to a logical conclusion. Perhaps her appropriations of postmodern feminism are shoddy. Or her magpie search for postmodern theories that support her thesis limits her discernment of theoretical correspondences between Michel Foucault, whom she quotes liberally, and Deleuze. Let me provide an obvious example. Where Garritano supports her accusation of Kuzwayo's illusory sovereignty of the author, she quotes Foucault: "[T]he author's name does not refer to a real person but that it exceeds the limits of the texts, that it organizes them, that it reveals their mode of being, or at least characterizes them ... the function of the author is thus characteristic of the mode of existence, circulation and operation of certain discourses within a society" (Foucault in Garritano 1997: 60). In the convenience of the quotation from Foucault she allows her scholarship to deliberately ignore a revealing correspondence with Deleuze, from whom, in the light of the theoretical dialogues between them, she could have gleaned an understanding of the gap between enunciation and utterance as they relate to woman-becoming in writing:

It is always an assemblage that produces utterances. Utterances do not have as their cause a subject which would act as a subject of enunciation, any more than they are related to subjects as subjects of utterance. The proper name does not designate a subject, but something which happens, at least between two terms which are not subjects, but agents, elements.

(Deleuze \& Parnet 1987: 51; my italics) 
Agents and elements are always in circulation in lines of flight, and the author-function serves to show the plane of immanence upon which some discourses are created and others undermined. The proper name, in this case, signifies a moment in the middle of wifehood and black womanhood and, as such, attests to the collocation of the subject of utterance and the subject of enunciation that in short, says Deleuze \& Foucault, mean the same thing. Perhaps Garritano's choice of Foucault over Deleuze, if she is aware of his work, represents her ideological interest. Take for instance her questioning of Black Consciousness's recourse to the past, or its charting of the "present" malaise of apartheid as against its absence in the past, however imperfect and her misreading the recourse as a romanticisation. She does not fully engage the politics of Black Consciousness beyond mere generalisation. Nor does she comprehend the educational value of girls who attended school at Lebollo, the initiation school where many "difficult lessons of adulthood and womanhood" were learnt (p. 71) as "a code of traditional moral values" (p. 16), which clearly remained important. Is this the bourgeois humanism Kuzwayo is accused of?

No, this is symptomatic of something that Garritano does throughout her essay: bluff summaries, even desultory name-dropping, followed by criticism or vindication of critical theorists. From the moment she opens her essay with a racy synopsis of Philippe Lejeune's notion of the fantasy of the "I" 7 and quickly creams "specific idenitity and creativity" off Carole Boyce-Davies, 8 she conveniently forgets to see the exhibition of a specific identity of a woman public figure as a creative part of a collective assemblage of utterances but then proceeds to say that "Call Me Woman lacks any significant amount of personal reflection and focuses instead on telling the stories of those women, including Kuzwayo, who have excelled in the political and public domains" (Garritano 1997: 58). Then, in the same breath, Garritano "the postmodern feminist" dismisses personal reflection when she gets it, criticising Kuzwayo for believing in words of the page or the ability of language to capture experience and "trap meaning in a net of signification" (Garritano 1997: 62). Perhaps, according to Garritano, the lives Kuzwayo records merely become signifiers that are malleable and are some kind of meaningless "play" of alternative history, devoid of neither political commitment nor material struggles.

When Garritano goes so far as to say that "[w]e never learn the names of the sons she is forced to leave behind" (Garritano 1997: 58-59) her selective reading becomes all the more unsettling and glaringly obvious. For the record: in the opening lines of Chapter 13, Kuzwayo declares in no uncertain terms that after a lot of achievements, including career mobility and

7. In setting up her argument, Garritano marshals Philippe Lejeune (1989).

8. Garritano misses an opportunity to evince a more credible reading of BoyceDavies (1994). 
the social status of a role in the film Cry the Beloved Country, "all these built me psychologically, emotionally and physically, but they could not wipe out my lasting, dear memories and dear longing for the loving sons I had left behind in Rustenburg: Matshwene (Everington) and Bakone (Justice) Moloto" (p. 180).9 Kuzwayo mentions a few pages later that a "prediction came true in 1958, when I saw my eldest son, Matshwene Everington Moloto, who was then 15 years of age, walk into my home" (p. 182), and the rest of the chapter deals with the struggles of Bakone at Fort Hare, mentioning his name no less than twelve times. Considering gross misreadings and unnecessary errors, Garritano herself could be accused of meaningless play as she superimposes Boyce-Davies's categories of silence as indicative of "the limits of propriety" (Garritano 1997: 59).

In sum, Garritano seeks to prioritise textuality over experience, as if the two were diametrically opposed or disparate. Self-writing, I have shown throughout, cannot be separated from memory and the experience or fantasy of it. It thrives on the crisis of gaps between experience and its textual representation, its writing against an inscribing socius, in a context of a struggle against the apartheid territorial machine and familial triangulation. Reconstructing that experience textually often means using the means of signification that already inhabit one type of discourse or another, thus readily positioning the narrative as a petit recit or an overtly political minor literature. Kuzwayo's citation of other women bespeaks their success despite their otherness as women and because of their self-definition as public figures. Her depicted experience, irrespective of the unreliable medium of language, dovetails with that of other women involved in the gendered struggle against phallocentricism, racism and capitalism. The problem is that critics such as Garritano might bring in their own subjective experience and project the "rights" discourses that shape it into their putatively postmodernist feminist criticism of Call Me Woman. This situation is not altogether new. Elleke Boehmer recalls this problem rather pointedly:

[I]mportant cultural differences, and differential experiences of powerlessness, were often ignored. Agency and rights, for example, were defined from a white American or European point of view with a stress on the individual. An unfortunate result of this was that stereotypes of the Third World as less liberated, less advanced, or mired in tradition and superstition, often resurfaced. The decisive intervention made by black/ex-colonized women writers and activists was to insist on the layeredness of women's experience, and on the validity of forms of self-expression and community other than those prevalent in the West.

(Boehmer 1995: 226; my italics)

9. It is a pity that reviewers for such a highly regarded international journal as Research in African Literatures could not pick this error up. 
Minus its one tendency to counter the communal tradition in Call Me Woman as not consistent with Black Consciousness, and perhaps another tendency of decrying the different authoring practices of women cited as achievers, Carmela Garritano's essay easily could have been the stuff of bravura. It is attenuated by its lack of both deftness in handling a rather promising postmodern feminist analysis and awareness of the pluralism of Deleuzean theory. I have demonstrated the case for rereading the textuality and experience of the autobiographies by Kuzwayo and Magona in the light of womanism and woman-becoming, acknowledging throughout the representational gap identified by Arnott, Spivak and Belsey as a collocation of the "in-between" and outside. I find such an analytical approach apt for demonstrating the double face of an assemblage through the foregrounding of autobiographical writing as exemplification of generative and transformative semiotic regimes of a Kafkaesque minor literature. This point is nowhere better illustrated by Kuzwayo's elucidation of the political struggle and triumphs of the individual woman who progresses beyond the disjunctive socius of the triangulated family in a manner that articulates to the broader collective agency of black South African women. According to Kuzwayo, "Minors' are heroines" (p. 243). Here is a deceptively simple story of mothers who become doctors, lawyers, social workers, etc., whose impact on society is palpable on the political scene. The political slant of Magona's and Kuzwayo's representational time attests to a constant transformation of fluxes of expression from the individual to the collective in a movement of shifts from an initial subject of enunciation to a subject of utterance.

\section{References}

Aegerter, Lindsay Pentolfe

$2000 \quad$ Southern Africa, Womanism, and Postcoloniality: A Dialectical Approach. In: Gover, Daniel, Conteh-Morgan, John \& Bryce, Jane (eds) The Postcolonial Condition of African Literature. Trenton, New Jersey: Africa World Press, pp. 67-72.

Arnott, Jill 1996

French Feminism in a South African Frame?: Gayatri Spivak and the Problem of "Representation" in South African Feminism. In: Daymond, Margaret J. (ed.) South African Feminisms. New York \& London: Garland, pp. 77-89.

Boehmer, Elleke

$1995 \quad$ Colonial and Postcolonial Literature: Migrant Metaphors. Oxford \& New York: Oxford University Press.

Boyce-Davies, Carole

1994 Black Women, Writing and Identity: Migrations of the Subject. London: Routledge. 
Deleuze, Gilles \& Guattari, Felix

$1986 \quad$ Kafka: Toward a Minor Literature. Minnesota: Minnesota University Press.

Deleuze, Gilles \& Parnet, Claire

1987 Dialogues, translated by Hugh Tomlinson \& Barbara Haberjam. New

Garritano, Carmela J. York: Columbia University Press.

1997 At an Intersection of Humanism and Postmodernism: A Feminst Reading of Ellen Kuzwayo's Call Me Woman. Research in African

Gilroy, Paul

1993 The Black Atlantic: Modernity and Double Consciousness. London: Verso.

Gqola, Pumla Dineo

1996 Reconsidering Motherhood in the Autobiographies of Ellen Kuzwayo and Emma Mashinini. In: Baderoon, Gabeba, Roper, Christopher \& Wittenberg, Hermann (eds) InterAction 4. Proceedings of the Fourth Postgraduate Conference. Bellville: UWC Press, pp. 47-52, reappears under the same title online:

Kuzwayo, Ellen

$<$ http//:www.uwc.ac.za/arts/English/interaction/95pg.htm>.

1985 Call Me Woman. London: Women's Press.

Lejeune, Philippe

1989 On Autobiography, translated by Katherine Leary, edited by Paul John Eakin. Minneapolis: University of Minnesota Press.

Magona, Sindiwe

$1992 \quad$ Forced to Grow. London: Women's Press.

Olney, James

1973 Tell Me Africa: An Approach to African Literature. Princeton:

Princeton University Press.

Pratt, Mary Louise

$1992 \quad$ Under Imperial Eyes: Travel Writing and Transculturation. New York: Routledge.

Raditlhalo, Sam

2009 The Self-Invention of Hugh Masekela. Journal of Literary Studies/ Tydskrif vir literatuurwetenskap 25(1): 34-52.

Smith, Sidonie 1993

Subjectivity, Identity and the Body: Women's Autobiographical Practice in the Twentieth Century. Bloomington: Indiana University Press. 